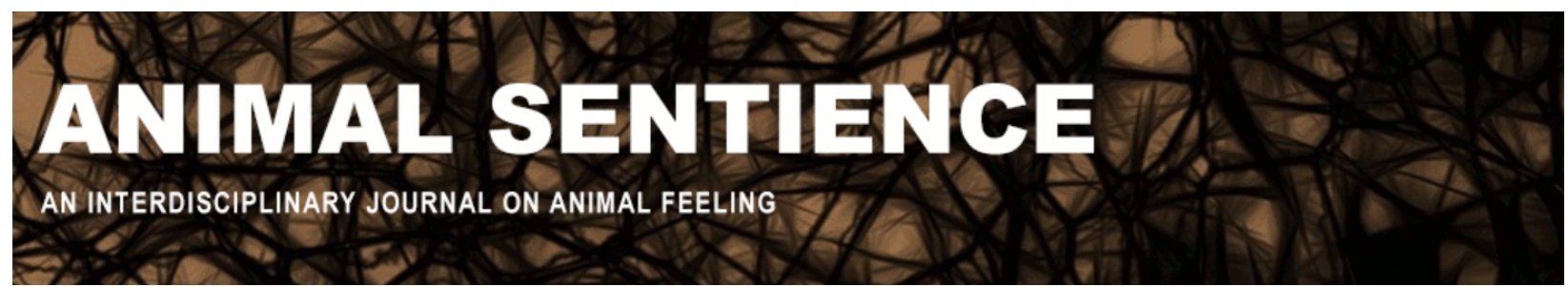

McGrew, William C. (2020) Practicalities of re-wilding. Animal Sentience 28(9) DOI: $10.51291 / 2377-7478.1567$

Date of submission: 2020-03-19

Date of acceptance: 2020-03-23

(c) (i)




\title{
Practicalities of re-wilding
}

Commentary on Baker \& Winkler on Elephant Rewilding

\author{
William C. McGrew \\ University of St Andrews, Scotland
}

\begin{abstract}
Re-wilding large-brained, intelligent mammals dependent on social learning to acquire survival skills is challenging. Each reintroduced species has different needs, but basic questions relating to essential aspects of successful release such as subsistence remain the same. Here I pose 12 ecologically and ethologically based questions that should be addressed (if not already done).
\end{abstract}

\begin{abstract}
William C. McGrew is Emeritus Professor of Evolutionary Primatology, University of Cambridge, and Honorary Professor, University of St Andrews. He spent 40 years (1972-2012) studying the ethology and ecology of chimpanzees (Pan troglodytes) and other primates, across sub-Saharan Africa ${ }^{1}$. Website
\end{abstract}

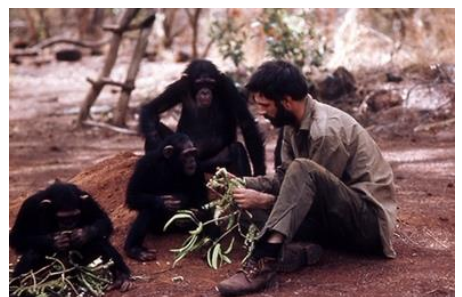

\section{Introduction}

Although my experience of elephants is limited to peripheral contacts over decades of field research on wild chimpanzees, I have some first-hand experience of reintroducing largebrained, socially multiplexed, wide-ranging, terrestrial tropical mammals into the wild and of working with refuges (e.g., Ron \& McGrew, 1988; Horvath et al., 2007). More precisely, my research team collaborated with Stella Brewer Marsden's project in Niokolo-Koba National Park, Senegal, which rehabilitated and released captive chimpanzees into the wild (Brewer, 1978).

Consequently, I was curious to see whether basic issues that raise challenges to be overcome have been addressed by Baker \& Winkler (2020) and the ensuing commentaries. Many were not or were only touched upon. I list some of these potential problems below, in the form of what I hope are pertinent questions. My ignorance of the elephant literature might make these points superfluous, but they should perhaps be aired.

\section{Foundational questions}

1. Have pre-release ecological and demographic studies/surveys been done at the proposed release sites, to assess their suitability?

2. Are the natural resources available, year-round, to support an insertion of new consumers into places with an existing population of resident wild elephants?

3. Has the carrying capacity of the habitat been assessed, taking account of the residents' population density?

4. Do resident elephants respond negatively to strange, immigrant competitors? (In chimpanzees, wild residents respond aggressively, even fatally, to newcomers.)

5. Is crop-raiding an issue when elephants accustomed to a captive diet become free-ranging?

\footnotetext{
${ }^{1}$ WCM seeks to convince rehabilitating chimpanzees that they should eat seeds of Parkia biglobosa, rather than the bananas, oranges, etc. that they were used to in captivity.
} 
6. Has there been a risk assessment of likely danger to the human population from released and free-ranging elephants?

7. What evaluations of exposure to and uptake of wild foodstuffs have been done on to-bereleased elephants?

8. Has the risk of predation (including human) on the released elephants been assessed?

9. Is the life-history of individuals being released known and evaluated, with regard to probability of successful transition to the wild? (In chimpanzees, it makes a big difference if the individuals are captive- or wild-born, and mother- or non-motherreared.)

10. Has the possibility of pathogen transmission from captivity to the wild (or vice-versa) been investigated, in terms of diseases, parasites, etc.?

11. Have the costs as well as the benefits to the ecosystem of releasing elephants been considered? (In southern Africa, over-populated elephants are culled because of the damage they cause to wild vegetation. They are not called 'bulldozer herbivores' without reason!)

12. Have the project's procedures been given ethical scrutiny and approval by the appropriate authorities?

I hope that all these considerations have been addressed, or will be!

\section{References}

Baker, L., \& Winkler, R. (2020) Asian elephant rescue, rehabilitation and rewilding. Animal Sentience 28(1).

Brewer, S. (1978) The chimps of Mt. Asserik. New York, NY: Alfred A Knopf.

Horvath, J.L., Croswell, M., O'Malley, R.C., \& McGrew, W.C. (2007) Plant species with potential as food, nesting material, or tools at a chimpanzee refuge site in Caddo Parish, Louisiana. International Journal of Primatology, 28, 135-158.

Ron, T., \& McGrew, W.C. (1988) Ecological assessment for chimpanzee rehabilitation project in Zambia. Primate Conservation, 9, 37-41. 


\section{Call for Papers}

\section{Special Issue of the Lournal of Consciousness Studies}

Plant Sentience: Theoretical and Empirical Issues

Guest Editors: Vicente Raja (Rotman Institute of Philosophy, Western University)

Miguel Segundo-Ortin (School of Liberal Arts, University of Wollongong)

In this special issue, we address the issue of plant sentience/consciousness from different disciplines that combine both theoretical and empirical perspectives. Some of the questions to be addressed in the special issue include the following:

- Plants exhibit interesting behaviors; does this entail that they are conscious to some extent?

- What are the requirements for a living organism to be conscious? Do plants meet these requirements?

- What does the possibility of plant sentience/consciousness entail for the study of the evolution of consciousness?

- Is it just a categorical mistake to attribute consciousness to plants?

- Can we talk about different levels or degrees of consciousness?

\section{How to submit?}

\section{Deadline: June $\mathbf{1}^{\text {st }}, \mathbf{2 0 2 0}$}

Please submit your papers (max. 9000 words including footnotes, references, abstract, etc.) to vgalian@uwo.ca with subject "Paper Special Issue JCS".

For more information, including bibliography and more detailed descriptions of the topics and questions to be addressed in the papers submitted to the special issue, please contact the guest editors at vgalian@uwo.ca (Vicente) or mso693@uowmail.edu.au (Miguel). 